\title{
ANALISIS PENGARUH PENGALAMAN TERHADAP KOMPETENSI SERTA PENGARUHNYA TERHADAP PRODUKTIVITAS UKM DI KOTA DENPASAR, PROVINSI BALI
}

\author{
I Wayan Chandra Adyatma* dan Desak Rurik Pradnya Paramitha Nida \\ Program Diploma IV Akuntansi Perpajakan, \\ Sekolah Vokasi Universitas Warmadewa, Denpasar-Bali, Indonesia \\ *e-mail: chandraadyatma8@gmail.com
}

\begin{abstract}
ABSTRAK
Penelitian ini bertujuan untuk mengetahui pengaruh pengalaman kerja terhadap kompetensi, serta pengaruhnya terhadap produktivitas UKM di Kota Denpasar. Analisis yang digunakan dalam penelitian ini adalah dengan menggunakan analisis jalur (Path Analysis) dengan model satu jalur. Data yang digunakan dalam penelitian ini merupakan data primer yang dibagikan kepada pelaku serta karyawan UKM yang ada di Kota Denpasar, kuisioner yang dibagikan berjumlah 100 buah kuisioner. Dari hasil penghitungan uji analisis yang dilakukan oleh peneliti, didapatkan hasil yang memberikan gambaran bahwa: (1) variabel pengalaman kerja menunjukan pengaruh signifikan dan positif terhadap produktivitas pelaku (pemilik dan karyawan) UKM di Kota Denpasar. (2) variabel kompensasi menunjukan pengaruh signifikan dan positif terhadap variabel produktivitas karyawan dan pemilik UKM yang ada di Kota Denpasar. (3) variabel pengalaman kerja menunjukan pengaruh signifikan dan positif terhadap variabel kompetensi UKM yang berada di Kota Denpasar Provinsi Bali.
\end{abstract}

Kata Kunci: UKM, Pengalaman Kerja, Kompetensi kerja, Produktivitas kerja

\section{PENDAHULUAN}

Perdagangan adalah kegiatan perekonomian yang menjadi sumber kehidupan sebagaian besar masyarakat, keuntungan yang di dapat dari berdagang mampu melebihi penghasilan yang di dapat dengan bekerja pada suatu perusahaan atau orang lain. Dengan semakin berkembangnya kegiatan perdagangan terutama yang berfokus pada usaha kecil dan menengah memiliki persaingan yang semakin ketat, inovasi dan kreatifitas merupakan salah satu hal yang harus terus di kembangkan untuk mampu bersaing dalam dunia usaha.
Persaingan usaha saat ini sangat kompetitif, diikuti dengan perkembangan teknologi dan informasi yang mudah diakses oleh siapa saja. Hal ini bisa dilihat dari semakin bertambahnya bisnis-bisnis baru.

Persaingan usaha yang semakin ketat disebabkan oleh bertambahnya UKM dan yang sifatnya musiman, sehingga menciptakan situasi yang mendorong agar setiap pemilik usaha mampu memberikan usaha dalam melakukan pekerjaan yang maksimal sehingga mampu bersaing dalam persaingan yang semakin ketat. Sumber Daya Manusia 
merupakan faktor utama dalam sebuah bisnis, perusahaan harus mampu mendidik dan melatih sumber daya manusiannya agar tetap unggul dan mampu bersaing baik dari segi kemampuan, sehingga bisa penyelesaian tugas dan tanggung jawab yang diembankan kepadanya dapat dilaksanakan dengan baik. Dalam hal ini pengalaman kerja sangat mempengaruhi tingginya tingkat kinerja serta produktivitas pekerja (Putra, 2016).

Dalam meningkatkan kualitas SDM, hal pertama yang harus dilakukan oleh pemilik usaha adalah melakukan perekrutan tenaga kerja yang memiliki pengalaman kerja yang relevan serta memiliki tingkat pendidikan yang cukup untuk bidang usaha tertentu, sehingga diharapkan mampu memberikan output yang baik bagi perusahaan. Pengalaman kerja dianggap mampu meningkatkan kreatifitas tenaga kerja melalui hal yang pernah dilakukannya di tempat kerja sebelumnya, kreatifitas dalam menyelesaikan masalah, serta antusiasme dalam meningkatkan kualitas diri untuk dapat bersaing di era revolusi industry 4.0. Dalam penelitian yang dilakukan oleh Nitisemito (2000: 62) menjelaskan bahwa fungsi pengembangan kualitas sumber daya manusia, kualitas diri, dan kemauan untuk bertumbuh harus dimiliki oleh semua sumber daya manusia yang ada di dalam perusahaan. Hal tersebut merupakan asset yang dimiliki perusahaan yang harus dijaga dan dikembangkan melalui penghargaan dan motivasi, sehingga diperlukan tenaga kerja yang memiliki pengalaman serta pendidikan yang sesuai dengan kriteria perusahaan untuk mampu menerima pelatihan yang berguna bagi perusahaan, maupun individu pribadi.

Kota Denpasar merupakan kota pusat bisnis baik itu besar maupun kecil yang berada di Provinsi Bali, sebagian besar warganya banyak bekerja di bidang pariwisata, namun tidak sedikit juga yang berkecimpung dalam dunia bisnis UKM. Menurut penelitian yang dilakukan oleh Andi (2017) banyaknya jumlah UKM di Kota Denpasar tidak diikuti dengan peningkatan tingginya kinerja pekerja UKM yang ada di sektor informal, mengakibatkan kurang puasnya pelanggan dalam mendapatkan servis serta pengalaman yang kurang baik saat melakukan transaksi dengan UKM. Hal tersebut didasari oleh kurangnya pelatihan dan pengalaman kerja yang diberikan oleh pemilik usahanya, sehingga secara tidak langsung, produktivitas kerjanya juga ikut menurun (Santhi, 2018). melalui data yang diperoleh dari Dinas Koperasi, UKM dan Perisdustrian Kota Denpasar terdapat 32.685 pelaku UKM di Kota Denpasar Provinsi Bali. Banyaknya pelaku Usaha Kecil, dan Menengah (UKM) di Kota Denpasar merupakan keuntungan tersendiri bagi Provinsi Bali terutama dalam mengokohkan tujuan kestabilan ekonomi daerah. Peran UKM adalah untuk dapat membantu mewujudkan pertumbuhan ekonomi, pemerataan, dan peningkatan pendapatan masyarakat, penciptaan lapangan kerja, dan pengentasan kemiskinan. 
Tabel 1

Jumlah UKM per tahun di Kota Denpasar

\begin{tabular}{cccccc}
\hline No & Nama Kecamatan & 2016 & 2017 & 2018 & 2019 \\
\hline 1 & Denpasar Utara & 9.573 & 11.260 & 10.045 & 10.727 \\
2 & Denpasar Barat & 792 & 11.212 & 11.804 & 11.605 \\
3 & Denpasar Selatan & 204 & 6.147 & 6.812 & 5.251 \\
4 & Denpasar Timur & 526 & 2.142 & 2.182 & 3.243 \\
\hline & Total & 11.905 & 30.761 & 30.843 & 31.826
\end{tabular}

Sumber: Dinas koperasi usaha mikro kecil dan menengah kota Denpasar Tahun 2019 (data diolah)

Dari data yang disajikan pada Tabel 1 , didapatkan angka sejumlah 31.826 UKM yang ada di Kota Denpasar, jumlah tersebut merupakan jumlah yang paling besar di Provinsi Bali. Namun menurut penelitian yang dilakukan oleh Andini (2018) mengenai produktivitas kerja karyawan UKM di Kota Denpasar menunjukan hasil bahwa sebagian besar tenaga kerja UKM di Kota Denpasar masih sangat rendah, hal ini dikarenakan oleh rendahnya pendidikan serta pengalaman kerja yang masih kurang. Tinggi rendahnya tingkat pendidikan memberikan pengaruh yang signifikan terhadap seorang tenaga pekerja dalam menyelesaikan pekerjaannya, hal tersebut dikarenakan kebiasaan seseorang dalam menyelesaikan masalah serta mencari solusi sangat dipengaruhi oleh kombinasi dari tingkat pendidikan dan pengalamannya. Dalam penelitian yang dilakukan oleh Eko (2012) tingkat pendidikan, pelatihan, dan pengalaman adalah faktor yang utama yang mampu mempengaruhi kinerja seorang tenaga kerja dalam melaksanakan pekerjaannya, dalam penelitiannya didapatkan hasil bahwa semakin tinggi pendidikan seorang tenaga kerja, semakin banyak pengalaman, serta semakin sering pelatihan yang diikuti oleh seorang tenaga kerja, maka produktivitas pekerjaannya semakin tinggi. Menurut Todaro (2000) dalam penelitiannya dijelaskan bahwa pendidikan mampu memberikan tambahan pendapatan bagi seseorang, hal ini dikaitkan dengan keterampilan dan pengetahuan yang didapatkan seseorang setelah menyelesaikan sebuah jenjang pendidikan, dijelaskan bahwa setiap rentang waktu satu tahun sekolah, maka mampu meningkatkan kemampuan dan keterampilan kerja seseorang yang akan memengaruhi tingkat penghasilnannya.

Pada penelitian yang dilakukan oleh Rahmawati (2004) tenaga kerja memerlukan contoh dari hasil kerjanya di masa lalu, pengalaman merupakan salah satu upaya dalam 
meningkatkan kualitas diri. Dengan adanya pengalaman, seorang tenaga kerja mampu mengatasi permasalahan yang baru dan menyelesaikan dengan segera permasalahan yang sejenis atau sudah pernah dilaluinya. Sumber daya harus terus mengalami peningkatan, karena dengan adanya perkembangan teknologi, manusia diharapkan mampu memberikan value atau sebuah hasil yang tidak kalah dari apa yang dikerjakan secara otomatis melalui penggunaan mesin. Manusia memiliki sebuah kemampuan yang berbeda dari mesin atau robot, yaitu kreatifitas dan spontanitas dalam melakukan kegiatan, sehingga manusia mampu lebih unggul dari mesin dan memanfaatkan teknologi dengan baik. Pendidikan memberikan seseorang kemampuan untuk berfikir secara kritis, kemampuan ini didapatkan dari hasil belajar dan proses menyelesaikan masalah, walaupun hal tersebut tidak selalu sama dengan apa yang terjadi dalam kondisi sebenarnya, namun mampu melatih pemikiran untuk biasa bertindak dan berfikir secara kritis dan rasional dalam mengambil keputusan, sehingga dengan semakin tingginya pendidikan maka makin kritis juga pemikiran seseorang dalam menyelesaikan permasalahan dalam pekerjaannya.

Adapun penelitian yang telah dilakukan sebelumnya memperlihatkan hasil yang berbeda. Penelitian dalam bentuk studi kasus yang dilakukan Dimas (2004) berfokus pada pengaruh dari variabel pengalaman kerja terhadap produktivitas kerja karyawan di rumah sakit Prof. Dr. Soeharso Surakarta memberikan kesimpulan bahwa pengaruh pengalaman kerja terhadap produktivitas bersifat negative dan tidak signifikan, tetapi variabel kinerja bersifat positif dan berpengaruh langsung terhadap produktivitas kerja karyawan, hal ini disebabkan karena sebagian besar responden memiliki pengalaman kerja yang tidak relevan dengan tempat kerjanya saat ini.

Penelitian yang dilakukan oleh Wibawa (2005) mengenai Pengaruh Pendidikan, Pelatihan dan Pengalaman Kerja Terhadap Produktivitas Kerja Keryawan CV. Berkah Rattanindo di Sukoharjo memperlihatkan adanya pengaruh yang besar dan signifikan antara variabel bebas dan terikat, variabel yang paling besar pengaruhnya adalah variabel pengalaman kerja yang sangat memengaruhi produktivitas tenaga kerja di perusahaan tersebut.

Hasil penelitian yang serupa di tunjukan dari penelitian yang dilakukan oleh Eliyani (2007) yang melakukan penelitian tentang sistem pengelolaan presensi dalam meningkatkan kedisiplinan pegawai yang pada akhirnya bertujuan untuk meningkatkan kinerja pegawai. Dalam penelitiannya disebutkan perlunya suatu sistem agar tenaga kerja mampu melakukan pekerjaan dengan baik, serta adanya sistem penghargaan yang diberikan bagi tenaga kerja yang berprestasi, hal tersebut yang dianggap mampu meningkatkan kinerja pegawai secara simultan.

Penelitian ini memiliki tujuan antara lain (1) Untuk mengetahui pengaruh 
https://ejournal.warmadewa.ac.id/index.php/wicaksana

pengalaman kerja terhadap kompetensi karyawan UKM di Kota Denpasar. (2) Untuk mengetahui pengaruh kompetensi terhadap Produktivitas UKM di Kota Denpasar. (3) Untuk mengetahui pengaruh pengalaman kerja terhadap produktivitas UKM di Kota Denpasar.

Hipotesis dalam penelitian ini yaitu: (1) Adanya pengaruh positif dan signifikan pengalaman kerja terhadap kompetensi karyawan UKM di Kota Denpasar. (2) adanya pengaruh positif dan signifikan kompetensi terhadap Produktivitas UKM di Kota Denpasar. (3) adanya pengaruh positif dan signifikan pengalaman kerja terhadap produktivitas UKM di Kota Denpasar.

Melalui penjelasan tersebut, peneliti merasa penting untuk melakukan penelitian dengan judul: "ANALISIS PENGARUH PENGALAMAN KERJA TERHADAP KOMPETENSI KARYAWAN SERTA PENGARUHNYA TERHADAP PRODUKTIVITAS KERJA UKM DI KOTA DENPASAR, PROVINSI BALI".

\section{TINJAUAN PUSTAKA}

\section{Produktivitas}

Produktivitas pada dasarnya dapat dilihat dari dua sisi, yaitu sisi individu dan sisi organisasi itu sendiri. Sisi organisasi menggambarkan bahwa perusahaan harus bisa meningkatkan nilainya baik itu peningkatan penjualan, tenaga kerja, dan nilai manfaat yang diberikannya bagi konsumen, sehingga perusahaan akan terus berkembang menjadi perusahaan yang besar dan bermanfaat bagi banyak orang. Dari sisi konsumen diharapkan bahwa seseorang mampu memberikan hasil atau kinerja yang semakin hari semakin baik, pada prinsipnya tidak jauh beda dengan sisi organisasi, yaitu memberikan yang terbaik dari hari sebelumnya (Kusnendi, 2003:8.4).

\section{Pengalaman Kerja}

Dalam penelitian yang dilakukan oleh Wariati (2015) dijelaskan bahwa pengalaman kerja adalah keunkan, keterampilan, dan kemampuan seorang individu untuk menyelesaikan pekerjaan yang dipengaruhi oleh pengetahuan dan informasi yang didapatkan dalam pekerjaan atau pendidikan lainnya di masa lalu, pengalaman yang semakin banyak cenderung membuat seseorang makin piawai dan cerdas dalam proses menyelesaikan suatu permasalahan. Penelitian yang dilakukan oleh Manullang (2008), menjelaskan bahwa pengalaman kerja sangat penting untuk digunakan sebagai pertimbangan dalam proses seleksi pegawai, hal ini dikarenakan diperlukan penyesuaian dan penyamaan persepsi tentang keterampilan apa dan posisi yang pas untuk meningkatkan kualitas dan profesionalitas kerja seorang karyawan.

\section{Kompetensi Karyawan}

Menurut Stephen Robbin (2007), kompetensi merupakan suatu nilai seseorang atas apa segala sesuatu yang mampu dilakukannya dengan baik di dalam suatu industri. Kompetensi seseorang dapat memegaruhi bagaimana orang tersebut 
bertindak, serta menggunakan keterampilannya dalam menyelesaikan suatu tantangan. Kompetensi juga berarti keahlian di bidang tertentu yang didapatkan dari hasil melakukan kegiatan secara rutin dan memberikan hasil berupa pengalaman bagi seseorang pekerja, yang secara langsung mampu meningkatkan kinerja probadi maupun organisasi.

\section{METODE PENELITIAN}

Metode yang digunakan dalam penelitian ini adalah menggunakan metode kuantitatif. Data primer diperoleh dari responden melalui wawancara dan menggunakan kuisioner yang dibagikan secara langsung, untuk kemudian di isi oleh masing-masing responden. Populasi dalam penelitian ini terdiri dari 1252 pemilik usaha yang memiliki karyawan lebih dari 3 orang yang berstatus pegawai tetap dalam Usaha Kecil Menengah yang berada di Kota Denpasar, Provinsi Bali. Teknik pengambilan sampel dalam penelitian menggunakan Purposive Sampling yang dikumpulkan dengan membagikan kuisioner atas ijin pemilik usaha terlebih dahulu. Dari hasil perhitungan dengan menggunakan rusmus Slovin yang ditetapkan melalui tingkat kesalahan 10 persen, didapatkan jumlah 100 sampel responden yang kemudian ditetapkan sebagai sampel penelitian yang dibagikan kepada UKM dengan memberikan selebaran dan link yang bisa diakses dan dikumpul dalam batas waktu tertentu.

Variabel yang diuji dalam penelitian ini adalah sebagai berikut: Variabel terikat (dependent) pada penelitian ini merupakan variabel produktivitas kerja. Sedangkan variabel bebas (independent) pada penelitian ini merupakan variabel pengalaman kerja karyawan dan pemilik UKM. Sedangkan untuk variabel intervening yang diujikan pada penelitian ini merupakan variabel kompetensi karyawan. Gambaran konsep dan kerangka berfikir penelitian ini, seperti di jelaskan pada Gambar 1.

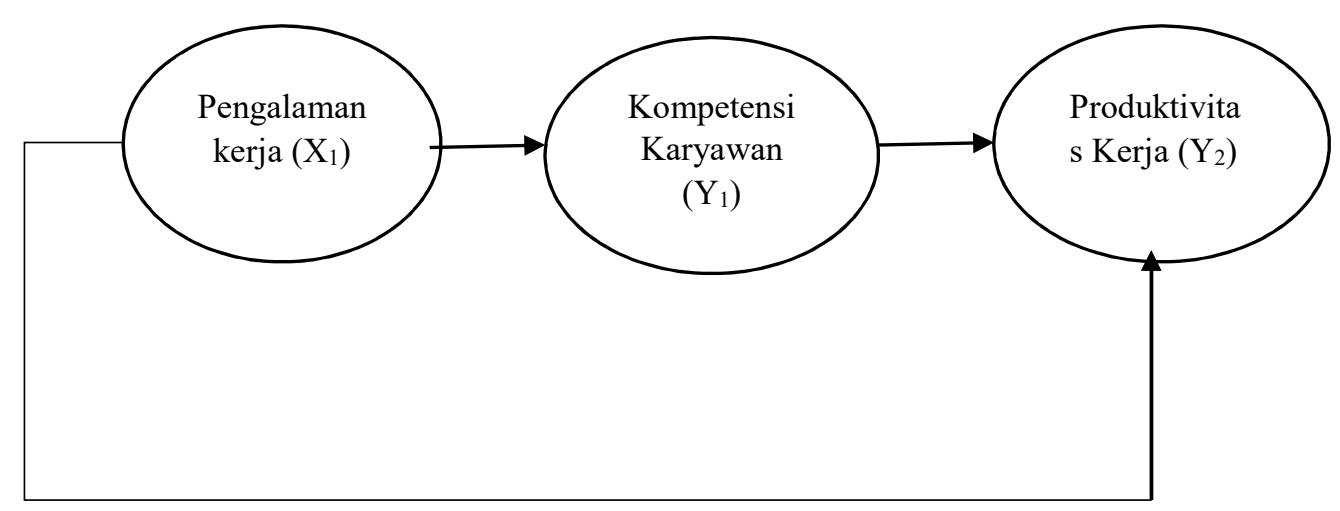

Gambar 1. Pengaruh pengalaman kerja terhadap produktivitas kerja, melalui variabel kompetensi karyawan 
Analisis Pengaruh Pengalaman Kerja Terhadap

Kompetensi Karyawan Serta Pengaruhnya

Terhadap Produktivitas Kerja Ukm Di Kota

Denpasar, Provinsi Bali. Penelitian ini menggunakan metode analisis jalur (Path Analysis) yang bertujuan untuk mengetahui pengaruh hubungan tiap variabel yang diuji.

\section{HASIL DAN PEMBAHASAN}

Penelitian ini menguji Pengaruh Pengalaman Kerja Terhadap Kompetensi Karyawan Serta Pengaruhnya Terhadap Produktivitas Kerja Ukm Di Kota Denpasar, Provinsi Bali. Pada tahap ini dilakukan pengujian terhadap kesesuaian model melalui telaah terhadap berbagai kriteria goodness of fit. Berikut ini hasil analisa goodness of fit indeks dari hasil uji full model disajikan pada Tabel 2.

Tabel 2

Goodness of Fit Index

\begin{tabular}{c|c|c|c}
\hline Goodness of Fit Measure & (Cut of Value $)$ & $\begin{array}{c}\text { Hasil } \\
\text { Analisis }\end{array}$ & $\begin{array}{c}\text { Evaluasi } \\
\text { Model }\end{array}$ \\
\hline Chi Square $(\lambda 2)$ & Diharapkan & & Marginal \\
& kecil $\leq 4,273$ & & \\
Significance Probability $(p)$ & $\geq 0,002$ & 0.007 & Baik \\
RMSEA & $\leq 0,06$ & 0,312 & Baik \\
GFI & $\geq 0,87$ & 0.872 & Baik \\
AGFI & $\geq 0,92$ & 0,265 & Baik \\
CMIN/DF & $\leq 2,50$ & 1 & Baik \\
CFI & $\geq 0,97$ & 0,872 & Baik \\
\hline
\end{tabular}

Sumber: hasil pengolahan data

Dari hasil pengujian kelayakan model (goodness of fit index) pada tahap yang terakhir pada Tabel 2, dapat dilihat nilai hasil dari goodness of fit index menunjukan bahwa penelitian ini memiliki analisis model yang sudah sesuai ( $f i t$ ) secara keseluruhan, serta ditunjukan juga adanya kesesuaian antara model dan data penelitian.

Untuk melihat besarnya nilai R-square yang menunjukan evaluasi terhadap goodness of fit index, dapat dilihat pada Tabel 3 sebagai berikut: 
Tabel 3

Square Multiple Correlations

\begin{tabular}{l|l}
\hline Nama Variabel & R-Square \\
\hline Kompetensi Karyawan $\left(\mathrm{Y}_{1}\right)$ & 0,523 \\
Produktivitas Kerja $\left(\mathrm{Y}_{2}\right)$ & 0,743 \\
\hline
\end{tabular}

Sumber: hasil pengolahan data

Dari hasil pengolahan data pada Tabel 3, dapat ditunjukan bahwa nilai $R$-square dengan nilai 0.523 untuk variabel Kompetensi Karyawan $\left(\mathrm{Y}_{1}\right)$, menyatakan bahwa model regresi untuk variabel (Y1) mempunyai nilai goodness-fit yang sangat baik, yang artinya variabel Kompetensi Karyawan (Y1) mampu dijelaskan melalui variabel (Y2) yaitu produktivitas kerja sebesar $56,40 \%$, sedangkan $47,70 \%$ sisanya dijelaskan melalui variasi dari variabel-variabel lain yang tidak ikut di teliti pada model dalam penelitian ini. Besaran nilai $\mathrm{R}$ square untuk variabel produktivitas Kerja $\left(\mathrm{Y}_{2}\right)$ yaitu sebesar 0,743 memiliki arti bahwa permodelan regresi dalam penelitian ini memiliki nilai goodness-fit yang cukup baik, yaitu dimana variabel terikat Y2 Produktivitas Kerja, mampu dijelaskan melalui variabel kompetensi karyawan sebesar $74,30 \%$ dan $25,70 \%$ dijelaskan oleh variabel lain yang tidak diteliti dalam model ini.

Berdasarkan hasil penelitian dapat diketahui bahwa Kompetensi Karyawan dan Produktivitas Kerja baik dan dapat dirpercaya untuk digunakan menjadi sarana pengumpulan data penelitian, hal ini dapat dibuktikan dengan nilai discriminant validity yang lebih besar dari 0,50 untuk nilai composite reliability dan AVE (average variance extracted) dan nilai cronbach alpha sebesar 0,90, yaitu lebih besar dari 0,60. Model structural dalam penelitian ini diuji dengan melihat nilai $R$-square atau pengujian goodness fit model. Evaluasi untuk model struktural yang digunakan dalam penelitian ini dapat dilihat dari besaran nilai $R$ Square yang mampu menggambarkan besarnya nilai dari variabel eksogen yang setelah dilakukan uji hipotesis penelitian, sudah dianggap bisa menjelaskan nilai besaran variabel endogen. Adapun pengujian model Rsquare dijelaskan secara rinci pada Tabel 3 
Tabel 4

Hasil Pengujian Path Coefficients (Mean, STDEV, T-Values)

\begin{tabular}{|c|c|c|c|c|c|c|}
\hline & $\begin{array}{l}\text { Original } \\
\text { Sample } \\
\text { (O) }\end{array}$ & $\begin{array}{l}\text { Sample } \\
\text { Mean } \\
(\mathrm{M})\end{array}$ & $\begin{array}{l}\text { Standar } \\
\text { Deviation } \\
\text { (STDEV) }\end{array}$ & $\begin{array}{l}\text { T Statistic } \\
(|\mathrm{O} / \mathrm{STERR}|)\end{array}$ & $\begin{array}{l}\text { Standar } \\
\text { Error } \\
\text { (STERR) }\end{array}$ & Ket \\
\hline Pengalaman-> Kompetensi & 0,765 & 0,825 & 0,046 & 18,365 & 0,052 & Sig \\
\hline Kompetensi-> Produktivitas & 0,428 & 0,352 & 0,209 & 2,527 & 0,137 & Sig \\
\hline Pengalaman-> Produktivitas & 0,298 & 0,211 & 0,211 & 2,372 & 0,062 & Sig \\
\hline
\end{tabular}

Sumber: hasil olah data penelitian

Hasil pengujian path Coefficient pada data di Tabel 4, menggambarkan hasil hubungan tiga variabel penelitian, yaitu variabel pengalaman dengan kompetensi, variabel kompetensi dengan produktivitas, serta variabel pengalaman dengan produktivitas. Hubungan antara variabel pengalaman dengan kompetensi, kompetensi dengan produktivitas, dan pengalaman dengan produktivitas menunjukan hasil yang signifikan dan positif dengan melihat nilai dari t-statistik yang lebih besar nilainya dari 1,96 .

Pengujian antar variabel yang dilakukan untuk melihat pengaruh tidak langsung antara variabel bebas (X1) pengalaman kerja terhadap variabel terikat (Y2) produktivitas kerja melalui intervensi dari variabel intervening (Y1) kompetensi karyawan sebesar 0,735 yang menunjukan pengaruh yang besar dan signifikan. Besarnya nilai pengaruh total yang dapat diinterpretasikan melalui perhitungan pengaruh variabel secara langsung maupun secara tidak langsung. Hasil penrhitungan pengaruh total antar variabel dalam penelitian menunjukkan bahwa yaitu pengalaman kerja berpengaruh positif dan signifikan terhadap kompetensi karyawan, kompetensi karyawan berpengaruh positif dan signifikan terhadap produktivitas kerja dan pengalaman kerja memiliki pengaruh yang positif serta adanya tingkat signifkansi yang tinggi terhadap variabel produktivitas kerja.

Melalui hasil perhitungan yang telah diuji dalam penelitian ini, didapatkan hasil penelitian yang menunjukan bahwa variabel bebas (X1) pengalaman kerja memiliki pengaruh yang positif dan signifikan terhadap variabel terikat (X2) produktivitas tenaga kerja. Dari hasil penelitian yang telah dilakukan, dapat diambil kesimpulan bahwa apabila pengalaman kerja yang dimiliki banyak maka produktivitas kerja UKM juga meningkat, begitu juga sebaliknya. Pengalaman kerja dikatakan sudah mampu memberikan berkontribusi terhadap peningkatan produktivitas kerja melalui kompetensi karyawan UKM di Kota Denpasar.

Perkembangan UKM di Kota Denpasar merupakan tujuan bersama dari peningkatan 
kegiatan perekonomian dan profesionalitas serta efektivitas UKM yang ada di Kota Denpasar untuk mampu memberikan kontribusi dalam kegiatan pemerataan pendapatan di Provinsi Bali. Menurut Suteja (2017) profesionalitas seorang karyawan didapatkan dari hasil pekerjaan yang sungguh-sungguh dan pengalaman kerja di berbagai jenis pekerjaan dan perusahaan. UKM yang produktif dan efisien memerlukan tenaga kreatif yang terampil dan cekatan dalam pengelolaan barang produksi, sehingga pengalaman mampu menggambarkan bagaimana seorang karyawan memiliki kompetensi yang tinggi dan produktivitas kerja yang baik bagi perusahaan. UKM merupakan salah satu penunjang kegiatan ekonomi masyarakat yang memiliki peranan sangat penting, maka dari itu, perlu dilakukan suatu usaha dalam meningkatkan produktivitas UKM secara nasional.

\section{SIMPULAN}

Melalui hasil penelitian, analisis dan pembahasan, dapat ditarik kesimpulan yang bisa disampaikan oleh peneliti, bahwa Pengalaman Kerja $\left(\mathrm{X}_{1}\right)$ berpengaruh positif dan signifikan terhadap produktivitas UKM $\left(\mathrm{Y}_{2}\right)$ di Kota Denpasar Provinsi Bali. Kompetensi karyawan $\left(\mathrm{Y}_{1}\right)$ memiliki tingkat signifikansi yang tinggi serta memiliki pengaruh yang positif terhadap variabel produktivitas UKM $\left(\mathrm{Y}_{2}\right)$ di Kota Denpasar Provinsi Bali. Sedangkan untuk variabel Pengalaman kerja $\left(\mathrm{X}_{1}\right)$ memiliki pengaruh yang positif serta memiliki signifikansi yang tinggi terhadap variabel produktivitas kerja $\left(\mathrm{Y}_{2}\right)$ melalui kompetensi karyawan $\left(\mathrm{Y}_{1}\right)$ UKM di Kota Denpasar.

Kegiatan UKM sering dipandang remeh oleh sebagian besar orang karena keuntungan yang didapat kadang tidak sebanding dengan resiko yang tinggi, namun setiap kegiatan pasti memiliki resikonya masing-masing. Hal yang perlu menjadi perhatian adalah diperlukannya pengelolaan UKM secara profesional, baik dalam kualitas barang yang diproduksi atau diperjual belikan, maupun dalam hal tenaga kerja. Pengalaman memberikan gambarang tentang bagaimana seseorang memandang suatu pekerjaan, terkait dengan inovasi dan caranya menyelesaikan permasalahan dalam perusahaan, produktivitas mampu dicapai dengan terus meningkatkan kompetensi seseorang yang didapat melalu pengalamannya melakukan suatu pekerjaan di tiap perusahaan yang memiliki budaya kerja yang berbeda, sehingga mampu beradaptasi merupakan skill yang harus dimiliki seseorang yang ingin terus berkembang dan bertumbuh.

\section{REFERENSI}

Agus, Suhendra, 2013. Faktor-faktor yang mempengaruhi produktivitas usaha tani kopi di Kecamatan Bukit Tinggi, Sumatra Utara.

Artayasa, Komang Ary, 2011. "Persepsi masyarakat miskin terhadap efektivitas penggunaan modal bantuan rumah tangga miskin, di Kecamatan Tabanan" Fakultas Ekonomi, Universitas Udayana. 
Augusty, Ferdinand. 2006. Metode Penelitian

Manajemen: Pedoman Penelitian

untuk skripsi, Tesis dan Disertai Ilmu Manajemen. Semarang: Universitas Diponegoro.

A.Ross, Steven, dkk, 1997. Pengantar keuangan perusahaan I. Salemba Jakarta.

Asmi, Suryani 2008 “Analisis pengaruh tenaga kerja, lama usaha, jumlah modal terhadap peningkatan produksi usaha tani bawang putih di DesaSukaharjo".Fakultas Pertanian, Universitas Padjajaran.

Atmaja, A. W. K. 2010. Hubungan Antara Persepsi Terhadap Pelatihan Kerja dengan Motivasi Kerja Pegawai Negeri Sipil di kantor Kecamatan Genuk Kota Semarang. Fakultas Ekonomi, jurusan Manajemen, Universitas Diponegoro.

Atmanti, Rismawan, 2005. "efektivitas dan dampak program community based development (cbd)-bali sejahtera dalam peningkatan kesempatan kerja dan investasi di kabupaten Tabanan". Tesis Magister Ekonomi Pembangunan, Universitas Udayana.

Akmal, Yori, 2006. Analisis Faktor-Faktor Yang Mempengaruhi Produktivitas Tenaga Kerja Industri Kecil Kerupuk Sanjai di Kota Bukittinggi, Fakultas Pertanian Institut Pertanian Bogor.

Artayasa, Komang Ary, 2011. "persepsi masyarakat miskin terhadap efektivitas penggunaan modal bantuan rumah tangga miskin, di Kecamatan Tabanan"
Asmi, Suryani 2008 “Analisis pengaruh tenaga kerja, lama usaha, jumlah modal terhadap peningkatan produksi usaha tani bawang putih di Desa Sukaharjo”

Atmanti, Rismawan, 2005. "efektivitas dan dampak program community based development (cbd)-bali sejahtera dalam peningkatan kesempatan kerja dan investasi di kabupaten Tabanan".

Bank Indonesia 2015 Pengertian UKM menurut Negara Indonesia dan Negara Asing

Basu, Sucita Dewa, 2005. "strategi peningkatan kinerja pekerja pada perusahaan konstruksi Hutama Karya melalui pendekatan budaya organisasi”.

BPS. 2019. Bali Dalam Angka tahun 20142019. Badan Pusat Statistik. Bali

Dinas Koperasi dan UMKM Provinsi Bali 2019. "Data jumlah UKM Provinsi Bali tahun 2014-2019”.

Erina, Winata, 2009. "Peran masa pendidikan dalam memediasi pengaruh faktor ekonomi, sosial dan demografi”".

Fitri, Kumala Sari dkk, 2011. "persepsi pelaku UKM terhadap efektivitas pelaksanaan program nasional pemberdayaan masyarakat mandiri perkotaan (pnpmmp) : studi kasus UKM Kabupaten Gianyar"

Hair, J.F. et all, (1998), Multivariate Data Analysis, Prentice Hall, New Jersey. 
Hair, Black, Babin, Anderson, Tatham (2006), Multivariate Data Analysis, $6^{\text {th }}$ edition, Pearson Prentice Hall, New Jersey.

Husein, Umar. 2011. Metode Penelitian Untuk Skripsi dan Tesis Bisnis Edisi 11. Jakarta: PT Raja Grafindo Persada

Ida Bagus Mantra . 2003.Demografi Umum. Edisi ke-2. Yogyakarta: Pustaka Belajar.

Jurnal Ekonomi Undiksha, 2012. "Jangka waktu kredit dan penyebab keterlambatan pembayaran usaha kecil dan menengah" Singaraja.

Kirana, Setyadewi, 2011. "Efektivitas dan dampak program community based development (cbd)-bali sejahtera dalam peningkatan kesempatan kerja dan pendapatan rumah tangga miskin di Kabupaten Klungkung”

Kuncoro, Haryo. 2007, Fenomena Flypaper Effect pada Kinerja Keuangan Daerah Kota dan Kabupaten di Indonesia, Simposium Nasional Akuntansi X, Makassar.

Mulyadi. 2009. Auditing. Jakarta: Salemba Empat Umar, Husein.2007. Metode Penelitian untuk Skripsi dan Tesis Bisnis. Jakarta : PT gramedia Pustaka.

Muliani, Dwi, 2012, "analisis daya beli, kredit, dan jam kerja terhadap peningkatan perekonomian pedagang "canang"di Pasar Ketapean, Kesiman, Denpasar Timur."
Mulyanto.2002."Potensi Pajak Daerah dan Retribusi Daerah di Kawasan Subosuka Wonosaren Propinsi Jawa Tengah (The Potential of Local Government Revenue : A Case Study in Subosuka Wonosaren District, Central Java Provincies)". Economics Faculty Sebelas Maret University. Surakarta.

Murdiana, Putu, 2008. "efisiensi penggunaan kredit rakyat untuk usaha peternakan ayam ras pedaging di kabupaten tabanan"

Muriani, Desak Ayu, 2011. "Pengaruh kinerja kredit terhadap alokasi pertumbuhan ekonomi pemerintah kabupaten/kota seprovinsi bali".

Musmini, Sri Ayu, 2013. "Analisis faktorfaktor yang mempengaruhi motivasi pengembalian kredit dan produktivitas usaha kecil dan menengah bimbingan dinas koperasi dan UKM Kecamatan Denpasar Timur".

Nata Wirawan, I Gusti Putu. 2002. "Cara Mudah Memahami Statistik 2 (Statistik Inferensia) untuk ekonomi dan bisnis", Denpasar : edisi kedua, Keraras Emas.

Novianti, Putri 2009. Faktor-faktor yang mempengaruhi produktifitas pertumbuhan usaha mikro, kecil, dan menengah Kecamatan Kuta Selatan.

Nugroho, Riant. 2009. Public Policy Teori Kebijakan (Analisis Kebijakan, Proses Kebijakan Perumusan Implementasi, Evaluasi, Revisi Risk Management 
Dalam Kebijakan Publik, Kebijakan

Sebagai The Fifth Estate, Metode Penelitian Kebijakan). Jakarta: PT. Elex Media Komputindo.

Rusman, Setyabudi, 2013. "analisis faktorfaktor yang berpengaruh terhadap pendapatan dan kredit rumah tangga pekerja kapal pesiar asal kota denpasar"

Saputra, Artana 2007. "analisis pengaruh faktor internal dan eksternal terhadap jumlah kredit dan dampaknya terhadap ketimpangan pendapatan antar pedagang pasar".

Semara, Adiputra, 2013. “Analisis faktor yang mempengaruhi peningkatan jumlah

produksi usaha pengolahan tahu dan tempe di Kecamatan Denpasar Barat

Todaro M.P. 2006. Pembangunan Ekonomi di Dunia Ketiga, Penerbit Erlangga, Jakarta. Undang-Undang RI Nomor 13 Tahun 2003 tentang Ketenagakerjaan

Urata, Shujiro, 2000, Policy Recommendation for SME Promotion in the Republic of Indonesia, JICA Report, Jakarta

Wijaya, Dansi, 2001. "pengaruh e-commerce terhadap customer satisfaction, trust, dan repeat usage layanan BCA mobile".

Wirawan, Kadek. 2012. "Pengaruh jumlah modal, tanggungan keluarga, dan pendidikan terhadap peningkatan jumlah penjualan usaha bakso lele di Kota Denpasar".

Wright, Sewall S. 1921. Correlation of causation. Journal of Agricultural

Research 20: 557-85.
Yamin, Sofyan \& Heri Kurniawan, 2009. SPSS Complete, Jakarta:

SalembaEmpat.

Yustia, Rini Dewi, 2001. "studi perbandingan rentabilitas bank sebelum dengan setelah penerapan manajemen risiko sesuai pbi nomor 11/25/pbi/2009 pada pt bank rakyat indonesia daerah bali"

Yuyun Wirasasmita (1994). Kewirausahaan : Buku Pegangan Jatinangor : UPTPenerbitan IKOPIN.

Zimmerer, dan Scarborough, 2008. Essentials Of Entrepreneurship And Small Business Management Kewirausahaan Dan Manajemen Usaha Kecil, Edisi 5 Buku 1, Salemba Empat, Jakarta. 